\title{
The University Library and International Understanding
}

\section{Dr. Strout is director, University of Den- ver Library.}

$\mathrm{I}^{\mathrm{N}}$ MPLICIT in any discussion of international understanding revolving, as it does, around the basic concepts of interchange of ideas, opinions and information, is the role of the library through its manifold programs of individual and group service by means of books and related materials. Such a conference as the one held at Estes Park, Colo., in June 1949, serves to bring into sharp focus certain facts and opinions indicative of the importance of this role, particularly as regards college and university libraries.

As a generalization it should be observed at the outset that by their comments and questions many of those in attendance at this conference (and the distinct majority were members of faculties of colleges and universities) betrayed an ignorance of or a lack of familiarity with the kind of service that all but the most poorly-equipped college or university libraries are prepared to give. Some of these services include the procuring of specialized materials, such as the publications of the U.S. Government, U.N. and Unesco; borrowing through

1 At the invitation of the American Council on Education, delegates representing agencies of government, professional organizations and associations met at Estes Park, Colo. June I9-22, I949, to discuss "The Role of Colleges and Universities in Furthering International Understanding." Over roo representatives of the various organizations which make up the council were in attendance, together with delegates from governmenta and private agencies, such as the U.S. Department of State, Unesco, and the Hazen Foundation. James Hodgon Ralph Fsterquest, and Donald E Strout represented the American Library Association, the last. named also serving as the representative of the A.C.R.L. interlibrary loan; and participation in the acquisition of nonbook materials, especially in the realm of audio-visual materials. For example, at one point the discussion hinged on the establishment on each campus of a clearing house of information on governmental and nongovernmental programs, on programs of study abroad and on related topics, such as exchange of foreign students. Certainly there is no better place on the academic scene for the provision of such information than the library, equipped as it is not only to initiate the collection of such information but also to see that it is kept up to date. Granted that this might require added personnel and consequently a larger budget, the Estes Park conference demonstrates clearly the need for such a service. At the same time it points to the need for far greater publicity regarding kindred services which up-to-date college and university libraries are already prepared to give.

What about the more specific aspects of the library's part in furthering a program of international understanding? Major "work areas" for the conference were defined as: U.S. governmental programs calling for cooperation with colleges and universities, intergovernmental programs, cooperation between voluntary organizations and colleges, the training of specialized personnel for positions bearing on international understanding, the curriculum and the advisory system, extracurricular activities, adult education, and the formation of an 
international organization of universities. As deliberations proceeded on these major work areas it became increasingly apparent that the full realization of the possibilities in each of these areas involves the library to some degree. By concept and tradition the library, certainly on the American scene and in some foreign lands as well, more nearly approaches the ideal of an international civil servant than any other one institution. If ever a concept, service, or formal organization possessed a degree of universality, it is the library. The U.S. libraries abroad, though not completely free from the taint of propaganda, do much in a direct way to further international understanding by bringing the United States closer to the hearts and minds of native populations. Similarly college and university libraries in this country can go far in furthering the cause of international understanding. The libraries could do this by providing the background information at the undergraduate level and by acting as centers of information for more specialized information at the graduate level- - such as information on research programs in international understanding being undertaken by the various voluntary, governmental and intergovernmental agencies, to mention but one example.

A few of the specific observations and recommendations coming out of the Estes Park conference may serve to show most adequately not only the direction of thinking of the conference, but may point to the ways in which the library can participate effectively in furthering a program of international understanding.

One section recommended the establishment of a national central coordinating committee or agency to act as a clearing house for the needs and services of governmental, intergovernmental and nongovernmental agencies on the one hand and colleges and universities on the other. ${ }^{2}$ The section working on the programs of intergovernmental agencies suggested that "basic kits should be developed and placed in institutions to answer the majority of questions regarding achievements, structure and problems of the [intergovernmental] agencies." 3 This section continued with the suggestion that a central committee should inform colleges and universities of the needs for specialized personnel as well as the opportunities for possible research and thesis topics presented by the issues under investigation by such agencies. ${ }^{4}$

The section concerned directly with aspects of cooperation between voluntary organizations and colleges and universities offered a specific recommendation that "voluntary agencies are encouraged to suggest to university libraries books and materials in the field of international understanding."5

In such matters as the creation of a university clearing house office, recommended by Section III, the individual library could well assume an active and continuing role. The establishment of such an office was recommended as an aid "toward building a more effective partnership between institutions of higher learning and voluntary organizations," 6 through the centralizing of information regarding foreign student affairs, student religions, cultural and humanitarian activities, and "all the existing points of contact between it as an institution and the voluntary organizations serving the campus community."7

Section VI recommends "a general basic course in international affairs which all

2 Report of Section I: "United States Government Programs That Call for Cooperation with Colleges and Universities." Russell I. Mackrey, chairman. (mimeo-

graphed) grams." Donald J. Shank, chairman. (mimeographed)

1 Ibid.

5 Report of Section III: "Cooperation between Voluntary Organizations and Colleges and Universities." A. Burns Chalmers, chairman. (mimeographed)

T I bid. 
students should be encouraged to take."8 There are definite library implications in that part of the recommendation calling for the provision of supplementary materials in a constantly expanding field. These implications are also present in the accompanying recommendations for the provision of courses for the student who wishes "broader training in the field of international relations, with or without any vocational intent,"9 on a myriad of topics ranging from the problem of war in modern society to a course on comparative literature.

The section on adult education noted the need for a representative specifically designated "to maintain contact with governmental, intergovernmental, and voluntary agencies as a means of securing speakers, information, and source materials for ... adult groups in the area served by the university."10 Such a representative could well be a member of the library staff, especially since the section urges, in another part of its report, a closer relationship between university and community groups in such matters as a speakers' bureau, the extension of library services, the provision of audio-visual and duplicating equipment, and the like.

A closer coordination, among colleges and universities, of information on programs involving liaison with foreign students and teachers on the individual campuses, as well as the sending of U.S. students to study abroad and the collection and dissemination of international information, as proposed by another section, ${ }^{11}$ falls properly and directly within the sphere of the services which the library is able to

\footnotetext{
8 Report of Section VI: "Curriculum and Advisory System." Helen Dwight Reid, chairman. (mimeo. graphed)

9 Ibid.

10 Report of Section VIII: "Adult Education." I. O. Horsfall, chairman. (mimeographed)

11 Report of Section VII: "Extra-curricular Activities." Rev. Vincent J. Flynn, chairman. (mimeographed)
}

provide, working closely, in such an instance, with other campus offices and organizations.

The college and university library becomes directly involved in any plans such as are under consideration for the formation of an international organization of universities (university in this sense referring to colleges and universities in the American sense) along the lines initially drawn at the Utrecht conference, Aug. 2-13, 1948, for which a full report has been published. ${ }^{12}$ The deliberations of this historic conference were continued and amplified from the American point of view at the Estes Park conference, which drew up a specific set of recommendations and suggested procedures, among which the following relates directly to the college and university library:

The conference firmly believes that there should also be some form of association among the universities of the world. A university has everything to gain by the development of closer official connection with sister institutions in other countries, which could be obtained under the auspices of such an association. The stimulation of research into problems of university life and work, and the holding of periodic conferences, could be better promoted by an organization of this sort than by any other. . . . ${ }^{13}$

One of the specific purposes of such an organization would be:

To administer an international Universities Bureau with the purpose of furthering directly or indirectly the following objects: a) the collection and dissemination of information relating to institutions of higher education throughout the world; as for example -... providing for the publication at regular intervals of comprehensive directories of institutions of higher education, establishing a

\footnotetext{
12 Unesco: Report of Preparatory Conference of Repre sentatives of Universities, convened at Utrecht, Aug. 2 13. 1948, by Unesco in collaboration with the Netherlands Government. (Unesco publication 228) Paris, Unesco, 1948 .

${ }^{13}$ Report of Section IX: "International Organization of Universities." Robert W. Goss, chairman. (mimeographed)
} 
library of works of reference and official publications of the various universities ... . d) the formation of measures for the better distribution and exchange of laboratory materials, books, and other equipment for university study and research among the countries of the world. ${ }^{14}$

The activities of librarians in general, and of college and university librarians in particular, in gathering books and other materials for the war-devastated areas are too well known to need further mention here. A letter from Alice Dulany Ball, of the U. S. Book Exchange, to Howard Lee Nostrand, executive officer of the conference, contains several specific suggestions which college and university librarians might consider carefully as ways and means of assuming a direct and positive role in the furtherance of international understanding and good will. Among other things the letter mentions:

(I) The shipment of books and book collections (late books, in good condition, in subjects useful to a modern college or research student) to U.S.B.E. which, though it cannot pay shipment costs to Washington, will sort, pack and arrange for costs of overseas shipment. (If the donor wishes to specify a given institution as recipient, this can be arranged, provided suitable groundwork for the gift has been laid.)

(2) The new CARE book program, in the purchase field, makes it possible for donors to choose the country, the type of institution, and the category of books to be sent, all with the same guarantee as other CARE shipments.

(3) The donation of current subscriptions to professional periodicals for institutions abroad, making use of the U.S.B.E. and the Unesco in Paris for names of institutions most in need of this service.

(4) The sending of books to individual scholars, students, and professors for their private use, along the lines of a plan which could be developed jointly by the State Department, A.L.A., U.S.B.E. and Unesco, which, along with other interested organiza-

$$
14 \text { Ibid. }
$$

tions, could develop the broad outlines of a program of requests and donations leading to the continued provisions of materials badly needed by such individuals overseas.

As was stated at the opening of this article, the role of the library is implicit in any program of international understanding. The individual library, libraries as a whole, and library organizations can perform a two-fold role: (I) As centers for the collection, organization and distribution of materials and information on all aspects of international understanding; and (2) as initiators of thought at the local and national level, regarding the understanding of international affairs, by discovering the persons and the outlets through whom such understanding can best be achieved and by taking a positive and aggressive part through active participation in furthering such understanding.

The specific and general ways by which libraries can fulfil this dual role are legion. The first step is the procurement of materials, such as the publications and lists of information from the United Nations. The more important step is the interpretation of these materials - to faculty, students and townspeople. The assistance in the compilation of lists of voluntary organizations, government needs and institutional resources, so urgently needed at the moment; the facilitating of dissemination of information throughout campus and community regarding provisions for foreign exchanges, foreign study programs, and the like; the systematic collection and interpretation of information regarding opportunities for study and research at foreign institutions as provided by their catalogs and announcements-by these ways and many others a college and university library can aid in the successful prosecution of a program leading to better international understanding.

$$
\text { (Continued on page II4) }
$$


The Person in the Body-Hensie-Norton

The Doctor's Job-Binger-Norton

The Happy Family-Levy and Monroe-

Knopf

Our Age of Unreason-Alexander-Lippincott

Living Wisely and Well-Terhune-Dutton

It's How You Take It-Caner-CowardMcCann

The History of Medical PsychologyZilboorg-Norton

The Emotional Problems of Living-English and Pearson-Norton

Fundamentals of Psychoanalysis-Alexander-Norton

Facts and Theories of PsychoanalysisHendrick-Knopf

Undue publicity for books of this type would probably not be justified. The fact that such books are in the library and available to all can be made known by suitable announcements on the usual bulletin boards or other normal publicity channels. Since psychiatry lends itself so readily to overstatements, and to exploitation by its wouldbe friends, it would probably be wise to let these books get into circulation slowly and naturally and let them make their own way. If, in the colleges and universities, interested departments stimulate their use, so much the better. In fact, each college librarian might well have a psychiatrist as an unofficial member of his advisory staff, to help him in the selection of new books in this field as they appear.
Librarians have in their hands the power of making or breaking the majority of new books. As recent figures compiled by the Library Journal show, United States public libraries buy from 1,000 to 3,000 copies of most of the trade books they decide to purchase. If books such as are on this list could be distributed to libraries in such quantities, true mental health might be a somewhat nearer possibility.

The aims of the librarian and the psychiatrist are really not very different in principle, though quite different in application. The librarian is the custodian of the information from which the student acquires the education which is to aid him in getting along with his fellows and living a full and satisfying life; but he is not satisfied with being merely the custodian. He exerts himself to make the raw materials of an education readily available in the face of very rapid multiplication of resources. Likewise the psychiatrist must come out of his isolation within the hospital and make the knowledge gained from the study of human failure of adjustment available to all the people in the hope of preventing emotional illness. As Iago Galdston has so well phrased it, "I do affirm that there is little hope for improvement in human relations until the body of knowledge available in modern psychiatry has been made common in the knowledge, thinking, and motivation of the common man."

\section{International Understanding}

\section{(Continued from page I09)}

It may be appropriate to close with one tangible example of what libraries can do in this program. Among the proposals adopted at the Estes Park conference was one which stated unequivocally the need for a good basic reading list to foster international understanding, which led to a for- mal request to the American Library Association to take the lead in the preparation of such a list. The effectiveness of such a list is very directly and intimately dependent upon the individual library-and the individual librarian-and the responsibility is a very grave one, indeed. 